\title{
A Rare Case of Tracheostomal Myiasis- A Case Report and Review of Literature
}

\author{
Sumana CV ${ }^{1 *}$, Betty Mariam Jacob ${ }^{1}$ and Suhel Hasan ${ }^{1}$ \\ ${ }^{1}$ Department of ENT, Mazumdar Shaw Medical Centre, India
}

Submission: April 03, 2020; Published: April 20, 2020

*Corresponding author: Sumana CV, Department of ENT, Mazumdar Shaw Medical Centre, Narayana Hrudayalaya Ltd, Bangalore, Karnataka, India

\section{Abstract}

Myiasis is the infestation of larvae of flies of the order Diptera, in humans. The larvae can infect various parts of the human body including, skin, necrotic tissues, and natural cavities of living persons. Myiasis in the tracheostomy stoma is very rare. We present one such case of myiasis in the tracheostoma in a 42 year old male patient who is a known case of retroviral disease and pseudobulbar palsy.

keywords: Myiasis; Tracheostomy stoma

\section{Introduction}

The term myiasis is derived from the Greek word "muia" which means fly. Hindu mythology describes myiasis as "God's punishment for sinners" [1,2]. Myiasis is the infestation of larvae of flies of the order Diptera in humans. The larvae can infect skin, necrotic tissues, and natural cavities of living persons. Myiasis can be primary if it infects intact skin, or secondary if it infects a previous injury site. Myiasis may be classified depending on the relationship with the host, as obligatory- which requires a live host for parasite survival, facultative -developing in live or dead organic matter, or accidental where they develop accidentally in an inappropriate host [3].

Myiasis is rare in the western countries. It is commonly seen in hot and humid climates in hot and humid climates in tropical and subtropical regions, such as underdeveloped areas of the Indian subcontinent, Africa, and Southeast Asia, which provide favorable breeding grounds for flies [4,5]. Myiasis can infest various parts of the human body. But Myiasis in the tracheal stoma is very rare and not many cases have been reported in the English literature. Here we report a case of Myiasis in the tracheostoma seen in a patient with retroviral disease and pseudobulbar palsy.

\section{Case Report}

A 42 year old male patient, a known case of retroviral disease on medication, presented with complaints of fever, redness and maggots at the tracheostoma site since 1 week. He had history of Multi Drug Resistant Tubercular Meningitis and Pseudo bulbar palsy with right sided hemiparesis and left sided hemiplegia, following which he was tracheostomised and was on PEG feeds. He was getting rehabilitative care at a local hospital in his village, where there was poor hygienic environment. Tracheostomy tube had not been changed since more than 2 years and did not receive regular tracheostomy tube and stoma care.

On examination, he was conscious and was obeying commands. He was tachypneic, tachycardiac and hypotensive, maintaining $95 \%$ oxygen saturation on room air. He was on size 7 cuffed tracheostomy tube with fowl smelling discharge from the wound. There was diffuse tender swelling around the stoma, with features of cellulitis, which was more on the left side. When the flange of the tracheostomy tube was lifted, multiple live maggots were seen in the stoma (Figure $1 \& 2$ ). As he was in septic shock, he was shifted to an isolation room in the ICU. He was resuscitated with IV fluids, vasopressors and IV antibiotics after taking culture from the tracheostomy wound and tracheal secretion. CT of the neck and thorax revealed soft tissue swelling and subcutaneous Edema with few air pockets surrounding tracheostomy site in a subcutaneous plane with no extension into the thorax (Figure 3).

After he was stabilized, visible live maggots were removed. Gauze soaked in turpentine oil (few drops only) was carefully placed around the stoma for few minutes. Turpentine oil has to be used cautiously to prevent chemical pneumonitis. After removing the gauze, few more live maggots were seen crawling out, which were removed. Wound was then cleaned and dressing was done. This was done twice daily for 3 days and then he was taken under General anaesthesia for exploration of the wound 


\section{Global Journal of Otolaryngology}

and tracheostomy tube change. Necrotic tissue and few more live maggots were removed (Figure 4 \& 5). A deep pocket under the skin was seen around the stoma on the left side, which was thoroughly cleaned. Tracheostomy tube was then changed with utmost care, avoiding entry of the maggots into the airway. In total, about 30 live maggots were removed.

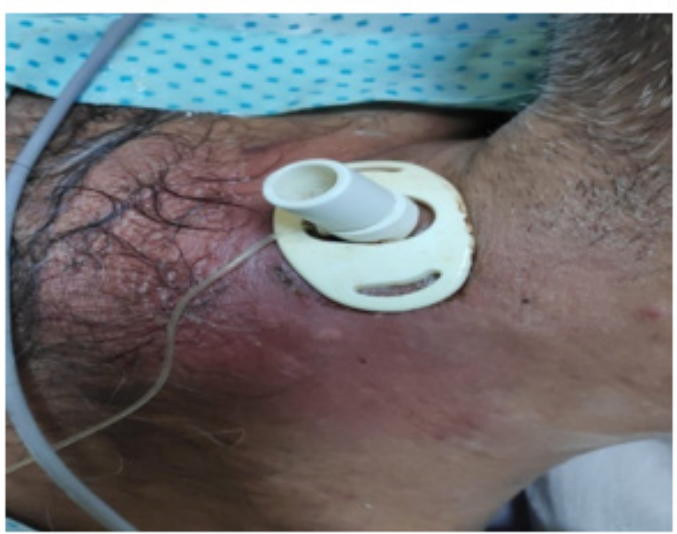

Figure 1: Cellulitis around the tracheostomy stoma.

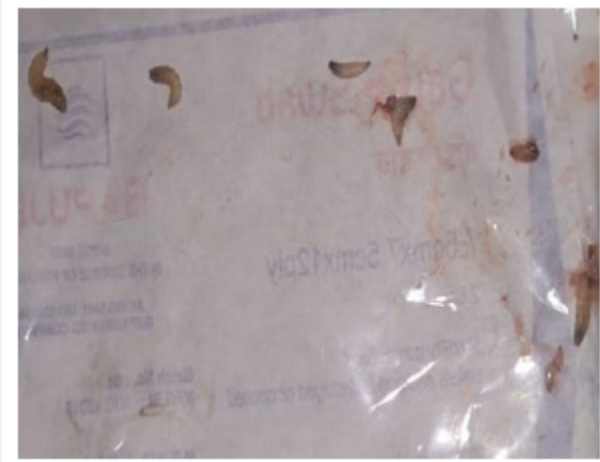

Figure 2: Maggots which were removed

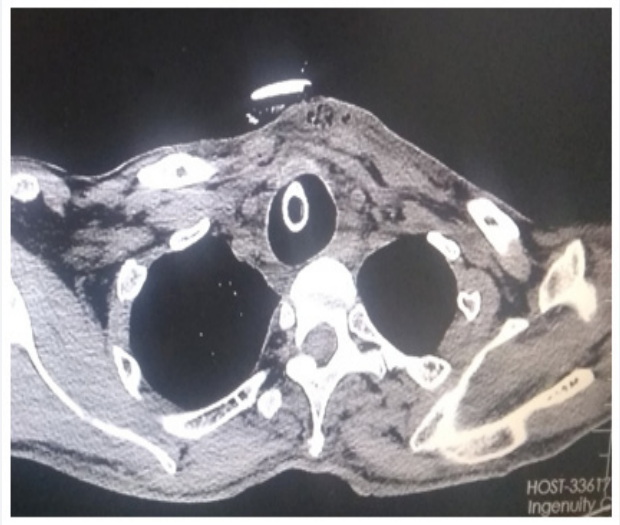

Figure 3: CT scan of Neck and Thorax showing soft tissue swelling and subcutaneous edema with few air pockets.

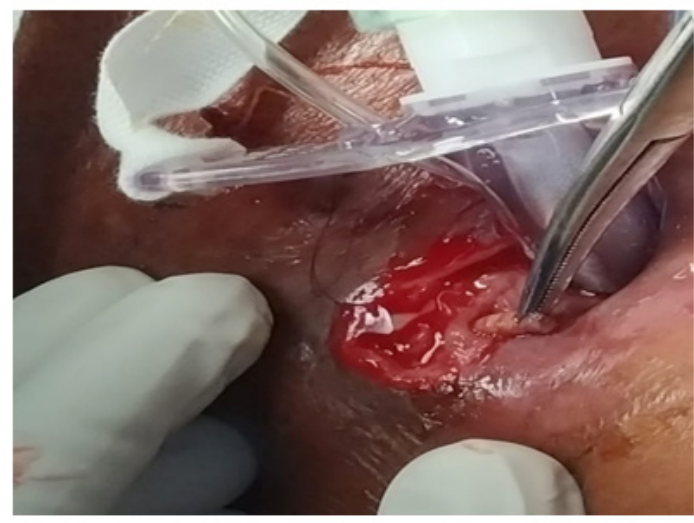

Figure 4: Live Maggot being removed.

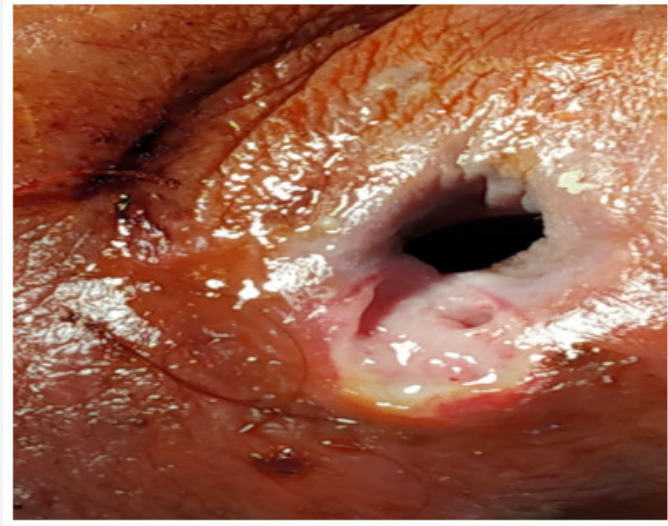

Figure 5: Necrosis around the stoma

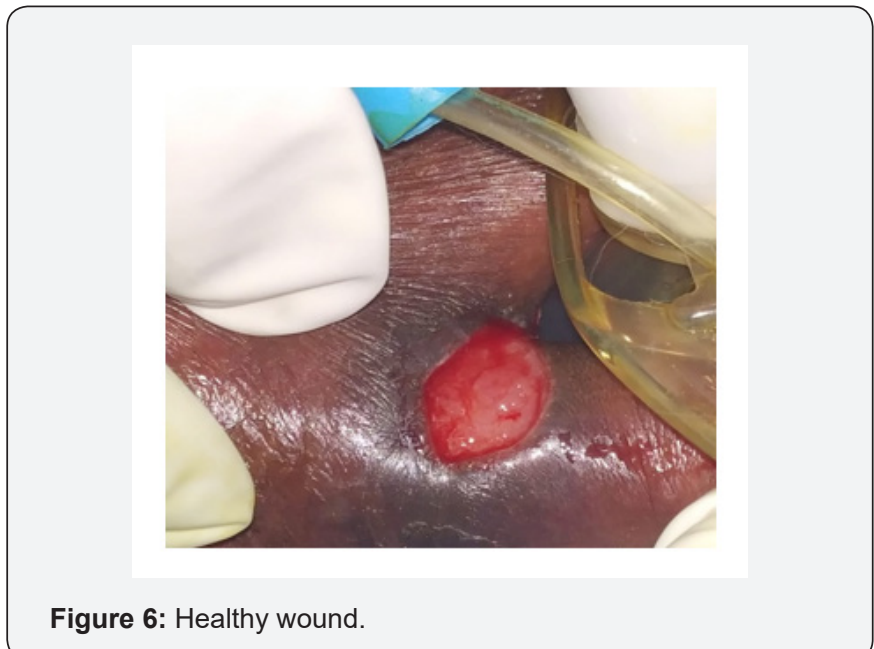

Gene Xpert from the tracheal aspirate was negative for Mycobacterium tuberculosis. Deep tracheal aspirate culture sensitivity grew E.coli, Strenotrophomonas maltophilia and Morganella Morgan. IV antibiotics were advised accordingly. With regular dressing of the tracheostomy stoma, the wound healed well in 2 weeks (Figure 6) and he was off vasopressor support. Flexible 


\section{Global Journal of Otolaryngology}

nasopharyngolaryngeal examination was done before discharge. He had pooling of saliva in bilateral pyriform sinus, vocal cords were mobile with mild phonatory gap and he was aspirating. So he was advised to continue PEG feeds and rehabilitative care. Patient's attenders were counselled and taught regarding regular tracheostomy wound care.

\section{Discussion}

Myiasis was defined by Zumpt in 1965, as the infestation of live human and vertebrae animals with dipterous larvae, which at least for certain period feeds on the host's dead or living tissue, liquid body substances, or ingested food [6]. Dipterous larvae can be classified based on the tropism of the tissue as [1]:

a. Cutaneous Myiasis- invading dermo-epidermal layers of the host

b. Myiasis of natural orifices- nose, ear, oral, pharyngeal myiasis c. Myiasis with inner migration- larvae migrate inside the body before emerging at skin level.

Tracheostomy stomal Myiasis is rare and very few have been reported in English literature. Predisposing factors for the development of myiasis are low socioeconomic status, unhealthy environments, exposed wound with fowl smelling discharge which attracts flies, advanced age, alcoholism, neurologic diseases, vegetative state of the patient, immunocompromised individuals, psychiatric illness and lack of personal hygiene [3,7]. Chigusa et al. [8] stated that patients with psychiatric disorders, elderly and debilitated persons, should be protected from flies, because of their autism and/or decreased sensitivity, which may make it easy for flies to deposit eggs or larvae on the patient's body surface or orifices [8]. Our patient was immunocompromised, living in unhygienic environment, paralyzed and his tracheostomy tube was not changed for a long time, which might have predisposed to develop Myiasis (Table 1).

Table 1: Review of literature of Myiasis in Tracheostomy stoma.

\begin{tabular}{|c|c|c|c|c|}
\hline Author and Country & Patient Age/Sex & Associated Conditions & Fly Species & Year of Publication \\
\hline Josephson RL [9] et al. Canada & $85 / \mathrm{F}$ & Comatose state & Unidentified & 1993 \\
\hline Franza R [1] et al. Italy & $57 / \mathrm{M}$ & Persistent vegetative state & Lucilea caesar & 2006 \\
\hline Batista da Silva JA [7] et al. Brazil & $49 / \mathrm{M}$ & Carcinoma of neck & $\begin{array}{c}\text { Cochliomyia homini- } \\
\text { vorax }\end{array}$ & 2011 \\
\hline Prasanna Kumar S [10] et al. India & $78 / \mathrm{M}$ & Head injury following Road traffic & Chrysomya bezziana & 2011 \\
\hline Bleijter J [11] et al. Argentina & $8 / \mathrm{M}$ & Cerebral palsy & Unidentified & 2012 \\
\hline Shakeel M [12] et al. India & $52 / \mathrm{M}$ & Carcinoma Larynx & Musca domestica & 2013 \\
\hline Hemanth V [13] et al. India & $73 /$ Not available & Carcinoma supraglottis and \\
Diabetis & Chrysomya bezziana & 2013 \\
\hline Kaya KH [14] et al. Turkey & $86 / \mathrm{F}$ & Tetraplegia & Lucilea caesar & 2014 \\
\hline Rajarshi S [15] et al. India & $62 / \mathrm{M}$ & Carcinoma supraglottis & Unidentified & 2015 \\
\hline Manickam A [16] et al. India & $57 / \mathrm{M}$ & Carcinoma glottis & Chrysomya bezziana & 2015 \\
\hline Virgilio E [17] et al. Peru & $67 / \mathrm{M}$ & Oesophagial carcinoma & $\begin{array}{c}\text { Cochliomyia homini- } \\
\text { vorax }\end{array}$ & 2016 \\
\hline Sharma R [18] et al. India & $2 / \mathrm{M}$ & Subglottic stenosis & Unidentified & 2017 \\
\hline Sumana CV et al. India & $42 / \mathrm{M}$ & $\begin{array}{c}\text { Retroviral disease, pseudobulbar } \\
\text { palsy }\end{array}$ & Unidentified & This study \\
\hline
\end{tabular}

Clinical features of myiasis are visible larvae in the wound, and secondary infection. Sometimes Lesions enlarge due to destruction of tissues causing necrosis. Treatment involves mechanical removal of all the larvae. Topical application like turpentine oil, ether, chloroform which is used commonly in other sites, should be used with caution at the tracheostomy stoma. These should not be used directly on the wound and minimal quantity soaked in gauze should be applied for few minutes, to prevent tracheal mucosal irritation and chemical pneumonitis. This suffocates the larvae which makes them migrate out of the wound to the surface, which can then be removed. It is important to avoid direct projection of light at the site of infestation to prevent migration of maggots into the trachea, as the larvae tries to move away from light $[9,10,19]$.

Thorough and regular cleaning of the wound is necessary. Sometimes, debridement and surgical exploration under general anaesthesia may be needed to remove necrotic tissue and deep seated larva. Single oral dose of Ivermectin $(0.2 \mathrm{mg} / \mathrm{kg})$, which is an antiparasitic drug has also been used as treatment for this kind of myiasis. Ivermectin has a broad antiparasitic spectrum that causes immobilization of parasites by inducing tonic paralysis of the parasite's muscles, mainly at the pharyngeal level, resulting in the death of the parasites by suffocation and starvation [17]. In our case, wound healed well even without the use of Ivermectin, as seen in other studies $[1,10,11,15,18]$. 
Systemic broad spectrum antibiotics are needed to prevent secondary infections. Underlying predisposing factors like nutrition and anaemia also needs to be addressed $[7,12]$. Preventive measures should be taken like maintaining good personal hygiene, preventing flies from entering houses and hospitals, daily dressing of tracheostomy stoma, regular suctioning of tracheal secretions, covering the tube by a fine wet gauze. Tracheostomy tube should be changed regularly.

\section{Conclusion}

Myiasis of tracheostomy stoma is very rare. Though not a lethal disorder, knowledge of this disease is necessary to prevent, diagnose and treat the condition. It can be fatal if it occurs near great vessels and vital organs. Management of myiasis needs precaution while removing maggots to prevent aspiration and cautious use of chemicals avoiding chemical pneumonitis. Otorhinolaryngologists should be aware of this disease, especially in the western countries where the incidence is very rare. It is important to educate the patient and relatives about the proper care of the tracheostomy tube and stoma and the need for regular follow up.

\section{References}

1. R Franza, L Leo, T Minerva, F Sanapo (2006) Myiasis of the tracheostomy wound: case report. Acta Otorhinolaryngologica Italica 26(4): 222-224.

2. Bosmia AN, Zimmermann TM, Griessenauer CJ, Shane Tubbs R, Rosentha EL (2014) Nasal myiasis in Hinduism and contemporary otorhinolaryngology J Relig Health 56(4): 1263-1281.

3. Francesconi F, Lupi O (2012) Myiasis. Clin Microbiol Rev 25: 79-105.

4. Vera L, Parkas S, Kumar A, Sachdev MS, Mandal AK (1990) External ophthalmomyiasis associated with herpes zoster ophthalmicus. Can J Ophthalmol 25(1): 42-43.

5. Sachdev MS, Kumar H, Roop, Jain AK, Arora R, et al. (1990) Destructive ocular myiasis in a noncompromised host. Indian J Ophthalmol 38(4): 184-186.

6. Zumpt F (1965) Myiasis in Man and Animals in the Old World, London Pp 267.
7. Batista da Silva JA, Moya Borja GE, Queiroz MMC (2011) Factors of susceptibility of human myiasis caused by the New World screwworm, Cochliomyia hominivorax in São Gonçalo, Rio de Janeiro, Brazil. J Insect Sci 11: 14

8. Chigusa Y, Kirinoki M, Yokoi H, MAtsuda H, Okada K, et al. (1996) Two cases of wound myiasis due to Lucilia sericata and L. illustris (Diptera: Calliphoridae). Med Entomol Zool 47: 73-76.

9. Josephson RL, Krajden S (1993) An unusual nosocomial infection: nasotracheal myiasis. J Otolaryngol 22(1): 46-47.

10. Prasanna Kumar S, Ravikumar A, Somu L, Vijaya Prabhu P (2011) Tracheostomal myiasis: a case report and review of the literature. Case Rep Otolaryngol 303-510.

11. Blejter J (2012) Tracheostomy wound myiasis in a child: case report and review of the literature. Case Rep Pediatr 317-862.

12. Shakeel M, Khan I, Ahmad I, Iqbal Z, Hasan SA (2013) Unusual pseudomyiasis with Musca domestica (housefly) larvae in a tracheostomy wound: a case report and literature review. Ear Nose Throat J 92: 38-41.

13. Hemanth V, Kumar CS, Manikandan D, Musarrat F, Preetham AP, et al. (2013) An unusual cause of late tracheostomy bleed. Case Reports Clin Med 2: 260-262.

14. Kaya KH, Güneş S, Erdim İ, Koç AK, Avcı A, et al. (2014) Tracheostomal myiasis in a female patient. Kulak Burun Boğaz Uygulamaları 2: 132134.

15. Rajarshi S, Ajay M, Jyoti RD, Siswati S, Jayanta S, et al. (2015) Management of tracheostomy site myiasis. Int J Clin Med Imaging 2: 8 .

16. Manickam A, Sengupta S, Saha J, Basu SK, Das JR, et al. (2015) Myiasis of the Tracheostomy Wound: A Case Report with Review of Literature. Otolaryngology 5: 198.

17. Failoc Rojas, Virgilio, Silva Diaz, Heber (2016) Review of Cases and a Patient report of Myiasis with Tracheostomy,Peru. Emerging Infectious Diseases 22(3).

18. Sharma R, Barathi KV, Saini R, Bairagi S, Rani D (2017) Tracheostomal myiasis! A word of caution. Indian J Anaesth 61: 936-937.

19. W R Wilson, W Lawrence, J Steckelberg, et al. (2001) Current Diagnosis and Treatment in Infectious Diseases. ( $1^{\text {st }}$ edn), McGraw-Hill Medical, p. 985.

\section{Your next submission with Juniper Publishers will reach you the below assets}

- Quality Editorial service

- Swift Peer Review

- Reprints availability

- E-prints Service

- Manuscript Podcast for convenient understanding

- Global attainment for your research

- Manuscript accessibility in different formats

( Pdf, E-pub, Full Text, Audio)

- Unceasing customer service

Track the below URL for one-step submission https://juniperpublishers.com/online-submission.php 
